\title{
KULTUROZNAWSTWO
}

Adam Bielinowicz

DOI 10.15290/sw.2020.20.24

Uniwersytet Warmińsko-Mazurski w Olsztynie

Wydział Teologii

Katedra Teologii Pastoralnej i Katechetyki

tel.: + 48509472372

e-mail: adam.bielinowicz@uwm.edu.pl

ORCID ID: https://orcid.org/0000-0002-4704-7864

\section{Działania na rzecz zachowania tożsamości narodowej, kulturowej i religijnej (na przykładzie współpracy Akademii Trzeciego Wieku w Olsztynie i polskich Uniwersytetów Trzeciego Wieku zza wschodniej granicy)}

Słowa kluczowe: tożsamość narodowa, tożsamość kulturowa, tożsamość religijna, edukacja, wychowanie, kultura, Kresy, pogranicze

\section{Wstęp}

Analizę podejmowanych działań służących zachowaniu tożsamości narodowej kulturowej i religijnej na przykładzie współpracy Akademii Trzeciego Wieku w Olsztynie (dalej ATW) z polskimi Uniwersytetami Trzeciego Wieku [dalej PUTW] działającymi m.in. na terenie Białorusi, Litwy, Rosji i Ukrainy, należy rozpocząć od krótkiej prezentacji znaczenia terminów tożsamość narodowa, tożsamość kulturowa i tożsamość religijna, gdyż nie są one jednoznaczne. Ponieważ istnieje wiele teorii i ujęć interpretacyjnych omawianych zjawisk, należy wyjaśnić, które z nich badacz przywołuje w swoich rozważaniach.

$\mathrm{Na}$ początku przede wszystkim należy wyjaśnić pojęcie tożsamość. Na potrzeby niniejszego opracowania przyjęto ujęcie słownikowe tego pojęcia. Tożsamość jest rozumiana jako świadomość istnienia własnej odrębności i pewnych cech, które określają każdą istotę ludzką i wynikają z potrzeby przynależności [Brzezińska, s. 50]. 
Warto zaznaczyć, że w zależności od celów i kontekstów, w których pojęcie tożsamość narodowa może być używane, jest ono różnie interpretowane [Ścigaj, s. 98 i nn]. Dalsze rozważania będą wynikały ze zdefiniowania to $\dot{z}$ samości narodowej jako poczucia odrębności wobec innych narodów, które jest kształtowane przez czynniki narodowotwórcze, takie jak m.in.: symbole narodowe, język, historia narodu, kultura, stosunek do dziedzictwa kulturowego, terytorium [Kornacka-Skwara, s. 113].

Definicję tożsamości kulturowej odnajdziemy między innymi w Słowniku etnologicznym, gdzie jest określona jako „najważniejszy rodzaj tożsamości zbiorowej, który polega na historycznie uwarunkowanym, kulturowym sposobie zachowania przez daną zbiorowość ludzką istnienia i ciągłości gatunku oraz równowagi biopsychicznej" [Kwaśniewski, s. 351-353]. Powyższa definicja eksponuje trzy ujęcia: pierwsze, w którym tożsamość to zjawisko doświadczane przez jednostkę, ale może także stanowić charakterystykę grupy; drugie prezentuje tożsamość jako wyraz postawy jednostki względem jej dziedzictwa przeszłości, wartości podzielanych także przez innych członków grupy, czyli tzw. podstawowych wartości; trzecie, według którego jest ona wynikiem zarówno kontaktów grupy w obrębie jej samej, jak i relacji z inną grupa [Waszczyńska, s. 56].

Dzieje Polaków są przykładem tworzenia się tożsamości kulturowej i narodowej oraz walki o jej zachowanie. Niemałą rolę w tych procesach odgrywa religia. Polska od ponad dziesięciu wieków jest ważną częścią składową świata chrześcijańskiego. „Równolegle z Polską rozwija się Europa, a właściwie christianitas; jest to określenie podstawowego kręgu cywilizacyjnego [...]. Praktycznie od początku kultura i świadomość Polski jest najściślej związana z tym światem, z tym kręgiem cywilizacyjnym" [Kłoczowski, s. 108]. Wskazanie narodowotwórczej roli religii wynika z analizy historii Polski, gdzie szczególnie podczas rozbiorów, w okresie wojen światowych, a następnie nastania epoki komunizmu, ważnym czynnikiem podtrzymującym świadomość narodową była właśnie identyfikacja religijna Polaków.

Tożsamość religijna $\mathrm{w}$ niniejszym opracowaniu jest rozumienia jako wewnętrzna autoidentyfikacja z rzeczywistością nadprzyrodzoną, tworzoną przez osobę w dynamicznym procesie integracji indywidualnego oraz społecznego obrazu religijności [Wieradzka-Pilarczyk, s. 99].

Kwestia poczucia tożsamości narodowej, kulturowej i religijnej zawsze była istotnym czynnikiem funkcjonowania narodu polskiego. Niemniejsza jest jej ranga w czasach współczesnych, kiedy dokonuje się nieustanna interakcja kultur. Została ona zapoczątkowana przez procesy, które dokonały się w wyniku wojen światowych ubiegłego wieku, kiedy to wiele tradycyjnych społeczności uległo rozpadowi. Miliony osób musiało opuścić rodzinne 
strony i osiedlić się w nowych miejscach. W wyniku tych zdarzeń znaczna część dotychczasowych więzi społecznych i kulturowych została osłabiona, a nawet utracona. System polityczno-gospodarczy, wprowadzony w państwach, w których władzę objęli komuniści, przyczynił się do podziału Europy na kraje rozwinięte i te, w których poziom jakości życia, służby zdrowia edukacji, wolności mediów, pozostawał na nieodpowiednim poziomie. Następnie przemiany z lat dziewięćdziesiątych zapoczątkowały zjawisko masowej migracji ludności. Natomiast współczesny rozwój komunikacji i wymiany myśli w oparciu o sieć Internet, przyczynił się w znacznym stopniu do powstawania społeczeństwa zglobalizowanego. Wspomniane procesy sprawiły, że dotychczasowe wartości, obyczaje i wielowiekowa tradycja, zaczęły zanikać. Z tego powodu zagadnienie kształtowania poczucia tożsamości narodowej, kulturowej i religijnej ciągle jest istotną kwestią, pozostającą w zakresie działania różnych organizacji, m.in. tych, które wymieniono w tytule niniejszego opracowana, czyli ATW i UTW.

\section{Historia działalności ATW}

W czasach współczesnych coraz wyraźniej dochodzi do głosu negatywne zjawisko polegające na braku akceptacji starości. Wielu ludzi nie akceptuje podeszłego wieku, wręcz boi się go. Sytuacja ta doprowadziła część społeczeństwa do różnorakich kryzysów, a nawet chorób. I chociaż obawy przed tym okresem życia, są naturalnym zjawiskiem, to jednak rozmiary, które przybiera w obecnych czasach wydają się niepokojące i wynikają z niewłaściwego rozumienia i godności ludzkiego życia. Osoby wchodzące w trzeci wiek stają przed wieloma nowymi problemami, z którymi do tej pory nie miały do czynienia. Często z powodu własnych ograniczeń i braku możliwości uczestniczenia w niektórych sferach życia społecznego, czują się marginalizowani i samotni. Na szczęście obecnie obserwuje się systematycznie zwiększającą się grupę osób starszych, które chcą mieć wpływ na kształt i jakość swojego życia. Coraz częściej obserwujemy upowszechniający się model aktywnego przeżywania wieku emerytalnego, którego podstawę stanowi świadomość faktu, że samorozwój człowieka może dokonywać się na każdym etapie jego życia. Dowodzą tego nie tylko indywidualne przypadki, ale powstające fundacje i stowarzyszenia, do których zaliczyć można ATW I UTW.

Geneza powoływania placówek dydaktycznych dla osób w wieku poprodukcyjnym, zwanym trzecim wiekiem, sięga początku lat siedemdziesiątych XX wieku. Wówczas to Pierre Vellas, profesor Uniwersytetu w Tuluzie, biorąc pod uwagę fenomen starzenia się społeczeństw na zachodzie Europy, 
zainteresował się gerontologią społeczną. W 1972 roku zorganizował spotkanie seniorów, aby rozeznać, czego oczekują oni od uniwersytetu. Następnie $\mathrm{w}$ kolejnych latach wydał serię artykułów związanych z geriatrią. Vellas jest uważany za twórcę pierwszego na świecie uniwersytetu trzeciego wieku w Tuluzie, który rozpoczął działalność w 1973 roku [Krygier, s. 3]. Niemal równolegle do powołania UTW w Tuluzie podobna placówka powstała w Warszawie.

Akademia Trzeciego Wieku w Olsztynie rozpoczęła swoją działalność 9 października 2008 roku uroczystą inauguracją nowego roku akademickiego. Inicjatorem powołani Olsztyńskiej ATW był Czesław Wojniusz, lider Koła Stowarzyszenia „Wspólnota Polska” w Olsztynie. Celem, który przyświecał powstaniu ATW, było założenie, że nowopowstała wspólnota będzie niezbyt liczna, co miało sprzyjać integracji słuchaczy i powstawaniu nowych inicjatyw. ATW jest członkiem Ogólnopolskiego Porozumienia Uniwersytetów Trzeciego Wieku w Warszawie. Od początku jej istnienia członkowie aktywnie współpracują z Warmińsko-Mazurskim Uniwersytetem Trzeciego Wieku w Olsztynie, Olsztyńską Szkołą Wyższą im. Józefa Rusieckiego w Olsztynie, Zespołem Szkół Budowlanych im. Żołnierzy Armii Krajowej i I Liceum Ogólnokształcącym w Olsztynie [Bagińska 2018]. Do statutowych celów tej organizacji zalicza się „aktywizowanie osób starszych poprzez uczestnictwo w różnych formach życia społecznego, a także upowszechnianie i popieranie różnych form aktywności intelektualnej, psychicznej i fizycznej adekwatnych do wieku, stopnia sprawności i zainteresowań członków" ${ }^{1}$.

Działalność UTW skupia się na dwóch głównych obszarach: organizacji wykładów i aktywizacji słuchaczy. Tematy wykładów skupione są głównie na tematach związanych z profilaktyką zdrowia fizycznego i psychicznego, psychologią, promocją zdrowego odżywiania się, przyrodą, filozofią, literaturą i sztuką, astronomią, a także historią. Natomiast aktywizacja słuchaczy dokonuje się głównie poprzez udział w zajęciach rehabilitacyjnych, korzystanie z basenu pływackiego; uczęszczanie na lektoraty języków obcych (język angielski i niemiecki dla poczatkujących i zaawansowanych), a przede wszystkim w ramach działalność kół zainteresowań. W ramach ATW aktywnie działają następujące koła: Koło Miłośników Kresów, osoba odpowiedzialna Czesław Wojniusz; Koło Miłośników Lasu i Militariów, osoba odpowiedzialna Anatol Leszczyński; Chór „De Novo”, osoby odpowiedzialne Maria Duch, Ryszarda Żuk-Kłębukowska; Koło Fotograficzne, osoba odpowiedzialna Elżbieta Konopacka-Romanowska; Taniec i Ruch, osoba odpowie-

1 Statut Akademii Trzeciego Wieku przy Miejskim Ośrodku Kultury w Olsztynie, §7. http://www.atwolsztyn.pl/p/dokumenty-do-pobrania.html [7.12.2019]. 
dzialna Barbara Dargiewicz; Filharmonia, osoba odpowiedzialna Ryszarda Żuk-Kłębukowska; Teatr, osoby odpowiedzialne Danuta Drożdżel, Danuta Drzewiecka, Elżbieta Miłaszewska; Koło Brydżowe, Elwira Gutkowska i Elżbieta Olejnik; Spotkania ze sztuką, Leszek Kranc; Grupa teatralna, Lucyna Samuś; Szkoła pleców, Alina Zmorzyńska; Wolontariat, Teresa Kowalska-Wojniusz; Koło rękodzieła, Janina Kluczek; Klub X Muzy, Barbara Krzemińska; Klub ludzi ciekawych świata, Krystyna Bańkowska; Koło turystyczne, Jerzy Broniek; Koło literackie, Jadwiga Zdanowska; Koło radiestezji i naturoterapii, Anna Kuklińska; Koło komputerowe, Eugeniusz Gajlewicz².

\section{Przykłady działań kształtujących tożsamość narodową, kulturową i religijną}

Z uwagi na ograniczenia dotyczące objętości tekstu, zostaną przedstawione wybrane działania na rzecz kształtowania tożsamości narodowej, kulturowej i religijnej, które zrealizowano podczas Europejskich Spotkań Integracyjnych PUTW (dalej ESIPUTW). Idea organizacji ESIPUTW narodziła się w 2006 roku podczas zebrania słuchaczy ATW i PUTW, które miało miejsce we Lwowie. W trakcie dyskusji jednogłośnie wyrażono potrzebę zorganizowania spotkań, w których uczestniczyłyby kilkuosobowe delegacje PUTW działające za wschodnią granicą. Celem, który przyświecał planowaniu organizacji spotkań, była: ,szeroko pojęta integracja w gronie Uniwersytetów Trzeciego Wieku zza wschodniej granicy i krajowych [...], wzajemne poznanie, nawiązanie i utrzymanie kontaktów i wsparcie naszych rodaków" [Bagińska, Bielinowicz, s. 64] a także, co wyraźnie zaznaczono we wnioskach składanych do Senatu Rzeczypospolitej Polskiej, „umocnienie tożsamości narodowej [...] poprzez organizację wydarzeń kulturowych [...] i religijnych" [Bagińska, Kłębukowski].

$\mathrm{W}$ celu umocnienia tożsamości narodowej $\mathrm{w}$ trakcie wszystkich spotkań zorganizowano wykłady i panele dyskusyjne dotyczące historii Polski, prowadzone m.in. przez prof. Stanisława Achremczyka i prof. Mieczysława Jackiewicza, związanych z Ośrodkiem Badań Naukowych im. Wojciecha Kętrzyńskiego w Olsztynie ${ }^{3}$.

2 Zob. http://www.atwolsztyn.pl/p/koa.html, [4.12.2019]

3 Wybrane tematy wykładów „Działania integracyjne na Warmii podejmowane w kontekście historycznym” (2007), „Polacy na Litwie, Białorusi i Ukrainie” (2008), „Dzieje Warmii” (2011), „Wykład o Koperniku” (2013), „Polacy na Kremlu” (2015), „Spotkanie z historią UWM” (2016), „Kresy dla Niepodległej” (2018). Zob. Bagińska A., Bielinowicz P., Wojnusz C., Sprawozdanie z ESIPUTW za lata 2007-2019, Archiwum ATW w Olsztynie. 
Realizując dążenie do ugruntowania tożsamości kulturowej uczestnicy spotkań brali udział w licznych wydarzeniach kulturalnych, które charakteryzowały się wysoką rangą i profesjonalnym przygotowaniem. Do ważniejszych wydarzeń należy zaliczyć występ orkiestry „Absolwent” ${ }^{4}$ oraz zespołów „Czerwony Tulipan" 5 i „Kortowianie” 6 a także koncerty muzyków i śpiewaków m.in. ks. dra hab. Zbigniewa Stępniaka7. Ponadto wśród wydarzeń kulturalnych należy wskazać wystąpienia artystyczne, przygotowane przez samych uczestników ESIPUTW, zarówno z kraju jak i z zagranicy ${ }^{8}$. Warto także podkreślić, że uczestnicy spotkań systematycznie uczestniczyli w pokazach filmowych ${ }^{9}$ i wycieczkach do miejsc związanych z kulturą i tradycją naszego regionu, m.in. do Gdańska, Kętrzyna, Lidzbarka Warmińskiego, Mikołajek, Rynu, Torunia i wielu innych ${ }^{10}$.

Podczas obrad wielokrotnie zwracano uwagę, na działalność PUTW za wschodnią granicą, służącą umacnianiu tożsamość kulturowej, której wyrazem jest troska o polskie zabytki i cmentarze za wschodnią granicą ${ }^{11}$.

Dbałość o język ojczysty jest niewątpliwie także dowodem działania na rzecz wzmacniania tożsamości kulturowej uczestników spotkań. W tym celu zorganizowano spotkanie z prof. Jerzym Bralczykiem, który wygłosił wykład "O ojczysta nasza mowo" i przeprowadził ożywioną dyskusję z uczestnikami ${ }^{12}$.

O skuteczności podejmowanych działań w zakresie pielęgnowania tożsamości narodowej i kulturowej świadczą wypowiedzi uczestników, które oficjalnie wygłoszono na zakończenie spotkań. Poniżej zostaną przedstawione trzy wypowiedzi, wybrane spośród kilkudziesięciu, których zapisy przechowywane są w archiwum ATW: 1) „W obecnej sytuacji integracyjne spotkania seniorów Polskich UTW zza wschodniej granicy w Olsztynie dają wspaniałą możliwość budowania więzi z Ojczyzną, wymiany doświadczeń, głębszego poznania polskiej historii i kultury. To właśnie te spotkania

\footnotetext{
4 Występ orkiestry odbył się w 2010 roku. Tamże.

5 Koncert odbył się w 2007 roku. Tamże.

6 Koncert odbył się w 2016 roku. Tamże.

7 Koncert odbył się w 2017 roku. Tamże

8 Wystąpienia artystyczne organizowane były podczas wszystkich trzynastu spotkań Tamże.

9 Seans kinowy filmu „Bogowie” (2015), seans w planetarium „Historii i współczesności Olsztyna" (2016). Tamże.

10 Wycieczki były organizowane podczas wszystkich spotkań. Tamże.

11 P. Bielinowicz, Notatka pisemna z rozmowy, Archiwum ATW w Olsztynie.

12 Wykład prof. Jerzego Bralczyka odbył się w 2019 roku. Bagińska A., Bielinowicz P., Wojnusz C., Sprawozdanie z ESIPUTW za lata 2007-2019, Archiwum ATW w Olsztynie.
} 
zainicjowały powstanie nowych Polskich UTW za wschodnią granicą” [Jankowski]; 2) „Trudno przecenić rolę, jako odgrywają te Spotkania w Olsztynie dla naszych UTW, ponieważ to nie tylko poznanie się z Polakami - Naszymi Rodakami, nawiązanie kontaktów pomiędzy naszymi UTW i innymi UTW w Polsce, czerpanie z wiedzy, korzystanie z doświadczeń, „dotykanie bezpośrednie historii Polski", - jak i wspaniałe głębokie przeżycia emocjonalne ze spotkania z Ojczyzną i Narodem, od którego przez dzieje historyczne zostaliśmy oderwani, ale przynależymy do Narodu polskiego i naszą Ojczyzną jest Polska...” [Fustoczenko]; 3) „Spotkania... w Olsztynie były wspaniałą okazją do poznania Polskiej historii i kultury, współczesnych problemów naszej Ojczyzny, możliwością doskonalenia znajomości języka polskiego, okazją do nawiązania przyjacielskich kontaktów nas Polaków zza Wschodniej Granicy z Polakami mieszkającymi w kraju. Zadaniem każdego z nas jest pozostawienie śladu, który zaowocuje w następnych pokoleniach, utrwalenie tych wartości, które nieśli nasi przodkowie - bogactwa kultury Polskiej" [Ściński].

W celu wzmocnienia tożsamości religijnej celebrowano uroczyste Msze, które odprawiano w kościele NSPJ w Olsztynie i w kościele akademickim w Olsztynie ${ }^{13}$ oraz na Wydziale Teologii UWM w Olsztynie ${ }^{14}$. Warto zaznaczyć, że „organizacja Mszy odbywała się nie tylko za zgodą, ale wręcz na wyraźne życzenie gości przyjeżdżających na spotkania i była przez nich bardzo pożądana" ${ }^{15}$. Uczestnicy spotkań wysłuchali wielu wykładów z zakresy teologii i historii Kościoła ${ }^{16}$. Ponadto w celu wzmocnienia tożsamości religijnej zorganizowano pielgrzymki do Sanktuariów w Gietrzwałdzie, Stoczku Klasztornym i Świętej Lipce ${ }^{17}$.

Jak bardzo rozwinęła się idea spotkań może świadczyć ich budżet, który w pierwszym roku wyniósł zaledwie 14,000 zł, następnie systematycznie z roku na rok wzrastał a podczas ostatniego spotkania zamknął się w kwocie 117,935.00 zł przekazanej przez Senat Rzeczpospolitej Polskiej. Ponadto pozyskano środki na organizację spotkań z Urzędu Marszałkowskiego Województwa Warmińsko-Mazurskiego w Olsztynie, Urzędu Miasta w Olsztynie i sponsorów. Do tego należy doliczyć pomoc wielu wolontariuszy, którzy ofiarowali nieodpłatnie swój czas, doświadczenie i ogromne zaangażowanie.

13 Msze odbyły się podczas wszystkich spotkań. Tamże.

14 Mszę zorganizowano w 2015 roku. Tamże.

15 P. Bielinowicz, Notatka pisemna z rozmowy, Archiwum ATW w Olsztynie.

16 Tematy wykładów: „Poczet biskupów warmińskich”, „Historia najstarszego seminarium duchownego w Polsce”, „Biblijny obraz świata”, Bagińska A., Bielinowicz P., Wojnusz C., Sprawozdanie z ESIPUTW za lata 2007-2019, Archiwum ATW w Olsztynie.

17 Pielgrzymki odbyły się w latach 2007, 2008, 2009, 2011, 2018, 2019. Tamże. 
O randze spotkań świadczą także przyznawane corocznie patronaty honorowe, których udzielał marszałek Senatu RP, wojewoda warmińsko-mazurski, marszałek województwa warmińsko-mazurskiego, prezydent Olsztyna, rektor Uniwersytetu Warmińsko-Mazurskiego.

W spotkaniach zazwyczaj uczestniczyli przedstawiciele mediów lokalnych, którzy obszernie relacjonowali wydarzenia. Wśród zaangażowanych mediów należy wymienić TVP 3 oddział w Olsztynie, Radio Olsztyn, „Gazetę Olsztyńską” oraz „Głos Seniora”. Nagłaśniane idei spotkań w lokalnych mediach niewątpliwie przyczyniło się do kształtowania tożsamości narodowej, kulturowej i religijnej nie tylko za wschodnią granicą, ale także wśród mieszkańców Warmii i Mazur.

\section{Zakończenie}

Celem spotkań w perspektywie wieloletniej jest budowa lokalnych, aktywnych społeczeństw obywatelskich na wszystkich piętrach wiekowych, poczynając od młodzieży szkolnej, poprzez osoby dorosłe do seniorów włącznie. Zauważalna aktywność osób starszych okazuje się dobrym przykładem dla młodszych pokoleń, które mają szansę stać się aktywnymi obywatelami. Po dokonaniu analizy programów spotkań i notatek zgromadzonych w archiwum ATW oraz informacji prasowych, należy jednoznacznie stwierdzić, że wśród celów, które udało się zrealizować podczas ESIPUTW było umocnienie tożsamości kulturowej, narodowej i religijnej Polaków żyjących w kraju i poza jego granicami.

\section{Literatura}

Bagińska A., Jesteśmy razem 10 lat!, [w:] 10 lat Akademii Trzeciego Wieku przy Miejskim Ośrodku Kultury w Olsztynie, [red.] A. Bagińska, W. Ziółkowska, P. Bielinowicz, Olsztyn 2018, s. 8-10.

Bagińska A., P. Bielinowicz, 2019, Impreza senioralna o zasiegu międzynarodowym pod tytułem „Trzynastego nawet w grudniu jest wiosna”. Trzynaście Europejskich Spotkań Integracyjnych Polskich Uniwersytetów Trzeciego Wieku, [w:] III wielki kongres UWT, 44 lata ruchu Uniwersytetów Trzeciego Wieku. Część I, [red.] K. Lewkowicz, Warszawa, s. 63-69.

Bagińska A., Bielinowicz P., Wojnusz C., Sprawozdanie z ESIPUTW za lata 2007-2019, Archiwum ATW w Olsztynie.

Bagińska A., Kłębukowski M., Załacznik nr 1 do Regulaminu konkursu. Oferta realizacji zadania publicznego wspótpraca $z$ polonia $i$ Polakami za granica [wnioski do Senatu RP z lat 205-2019], Archiwum ATW w Olsztynie.

Brzezińska A., 2006, Dziecinstwo i dorastanie: korzenie tożsamości osobistej $i$ spo- 
tecznej, [w:] A. Brzezińska, A. Hulewska, J. Słomska [red.], Edukacja regionalna, Warszawa.

Fustoczenko B., Przemówienie doc. dr Barbary Fustoczenko, rektor Uniwersytetu Trzeciego Wieku w Grodnie przy ZS „Polska Macierz Szkolna” na Białorusi, Archiwum ATW w Olsztynie.

Jankowski A., Przemówienie Prezesa Polskiego UTW w Solecznikach na Litwie podczas VIII spotkania w dniu 1 lipca 2014 roku, Archiwum ATW w Olsztynie.

Kłoczowski J., Patriotyzm polski w dtugim trwaniu, [w:] Patriotyzm wczoraj i dziś. Seminarium Polskiej Akademii Umiejętności 2002, Kraków 2003.

Kornacka-Skwara, E., 2011, Tożsamość narodowa w świetle przemian kulturowych, „Prace Naukowe Akademii im. Jana Długosza w Częstochowie. Pedagogika” nr 20, s. 113-120.

Krygier A., 2013, Założyciel pionierskiego Uniwersytetu Trzeciego Wieku-Profesor Pierre Vellas, „Ogólnopolski biuletyn UTW” nr 2, s. 3-4.

Kwaśniewski K., 1987, Tożsamość kulturowa, [hasło w:], Stownik etnologiczny. Terminy ogólne, [red.] Z. Staszczak, Warszawa, s. 351-353.

Ścigaj P., 2012, Tożsamość narodowa. Zarys problematyki, Kraków.

Ściński, W., Wystapienie inż. Wtadystawa Ścińskiego - Prezes Katolickiego UTW we Lwowie Filia Mokotowskiego UTW, Archiwum ATW w Olsztynie.

Waszczyńska K., 2014, Wokót problematyki tożsamości, „Rocznik Towarzystwa Naukowego Płockiego" nr 6, s. 48-73.

Wieradzka-Pilarczyk A., 2015, Tożsamość religijna młodych Polaków, Poznań.

\section{Netografia}

http://www.atwolsztyn.pl/p/koa.html, [4.12.2019]

http://www.atwolsztyn.pl/p/dokumenty-do-pobrania.html [7.12.2019].

\section{ACTIONS TO PRESERVE NATIONAL, CULTURAL AND RELIGIOUS IDENTITY (ON THE EXAMPLE OF COOPERATION \\ OF THE THIRD AGE ACADEMY IN OLSZTYN AND POLISH UNIVERSITIES OF THE THIRD AGE FROM BEYOND THE EASTERN BORDER)}

ABSTRACT

Key words: national identity, cultural identity, religious identity, education, upbringing, ulture, Kresy, borderland

This study attempts to explain the role played by the Third Age Academy in Olsztyn in preserving the national, cultural and religious identity of Poles living in the country and abroad. This goal is served by, among others, annual European Integration Meetings of Polish Universities of the Third Age from beyond the eastern border, organized for 13 years in Olsztyn. The article presents a historical outline of meetings and activities, thanks to which there is a chance to build local and active civil societies. 